\title{
The Helper Component-Proteinase of Sweet potato feathery mottle virus Facilitates Systemic Spread of Potato virus $X$ in Ipomoea nil
}

\author{
S. Sonoda, H. Koiwa, K. Kanda, H. Kato, M. Shimono, and M. Nishiguchi
}

\begin{abstract}
First, fourth, fifth, and sixth authors: National Institute of Agrobiological Resources, Kan-nondai 2-1-2, Tsukuba, Ibaraki 305-8602, Japan; second author: Iwate Biotechnology Research Center, Kitakami, Iwate 024-0003, Japan; and third author: Iwate University, Morioka, Iwate 020-8550, Japan.

Current address of S. Sonoda: Research Institute for Bioresources, Okayama University, Kurashiki, Okayama 710-0046, Japan. Current address of K. Kanda: Hitachi Central Research Institute, Hitachi Company Ltd., Kokubunji, Tokyo 185-8601, Japan. Current address of H. Kato: Fukui Prefectural University, Yoshida, Fukui 910-1195, Japan. Accepted for publication 11 May 2000.
\end{abstract}

\begin{abstract}
Sonoda, S., Koiwa, H., Kanda, K., Kato, H., Shimono, M., and Nishiguchi, M. 2000. The helper component-proteinase of Sweet potato feathery mottle virus facilitates systemic spread of Potato virus $X$ in Ipomoea nil. Phytopathology 90:944-950.

When Ipomoea nil was coinfected with Sweet potato feathery mottle virus (SPFMV), a member of the genus Potyvirus, and Potato virus $X$ (PVX) typical symptoms caused by PVX were observed on those by SPFMV on the first upper true leaves at 14 days postinoculation (dpi). On the other hand, no PVX-induced symptoms were observed on the first upper true leaves at 14 dpi when plants were infected with PVX alone. In the case of coinfection with PVX and SPFMV, PVX RNA was detected not only in the

inoculated cotyledonary leaves but also in the first upper true leaves at 14 dpi. In the case of single infection with PVX, PVX RNA was detected in the inoculated cotyledonary leaves but not in the first upper true leaves at 14 dpi. The accumulation of SPFMV remained unchanged, regardless of whether the inoculum consisted of SPFMV alone or a mixture of SPFMV and PVX. Although recombinant PVX engineered to express the helper component-proteinase (HC-Pro) of SPFMV (PVX.HC) enhanced symptoms severity in Nicotiana benthamiana, PVX.HC induced the synergism characterized by an enhanced viral movement in Ipomoea nil. Immunofluorescence microscopic examination revealed that the HC-Pro was present in phloem of SPFMV-infected I. nil. These results suggest that SPFMV HC-Pro acts as an enhancer of long distance movement for PVX in I. nil.
\end{abstract}

The genus Potyvirus belongs to the picornavirus-like supergroup of positive-strand RNA viruses and represents the largest and economically most important group of plant viruses (15). Members of this genus have flexuous rod-shaped virions with RNA genomes of $\approx 10 \mathrm{~kb}$ with a $5^{\prime}$ covalently linked viral-encoded protein $(\mathrm{VPg})(10,18)$. Potyviral proteins are released from a single polyprotein by viral proteinase-mediated processing events involving three known virally encoded proteinases: P1, helper component-proteinase (HC-Pro), and small nuclear inclusion protein (NIa) $(10,18)$.

Potyviruses interact with unrelated viruses, and the mixed viral infections result in enhanced symptoms more severe than the sum of those induced in either single infection. The synergistic interactions of potyviruses Tobacco vein mottling virus (TVMV) and Tobacco etch virus (TEV) with Potato virus X (PVX), a member of the genus Potexvirus, in Nicotiana plants have been extensively characterized at the molecular level $(17,28,29)$. In these synergisms, a dramatic increase of PVX (-) strand accumulation, up to 30 -fold in the first systemically infected leaves of coinfected plants, correlates with the enhanced symptoms. In contrast, the accumulation of the potyvirus remains essentially unchanged. Pruss et al. (17) showed that transgenic tobacco plants expressing the $5^{\prime}$ proximal region (P1/HC-Pro sequence) of the potyviral genome developed synergistic disease when they were infected with unrelated viruses including PVX, Tobacco mosaic virus, a member of the genus Tobamovirus, and Cucumber mosaic virus

Corresponding author: M. Nishiguchi; E-mail address: mnishigu@ abr.affrc.go.jp

Publication no. P-2000-0718-01R

(C) 2000 The American Phytopathological Society
(CMV), a member of the genus Cucumovirus. Recently, these potyviral synergistic interactions with unrelated viruses were proposed to occur through suppression of a host defense mechanism mediated by the potyviral HC-Pro $(1,5,12)$. These studies were performed in Nicotiana plants, and further study remains to test the mechanism of potyvirus-induced synergisms in the other plants.

In the present study, we examined the interactions between the severe strain of Sweet potato feathery mottle virus (SPFMV), a member of the genus Potyvirus, and unrelated virus PVX in Ipomoea nil. The effect of SPFMV HC-Pro on PVX pathogenicity, replication, and movement was also examined in I. nil. Furthermore, in vivo localization of HC-Pro in SPFMV-infected I. nil was microscopically analyzed.

\section{MATERIALS AND METHODS}

Viruses and plants. The host plants used in this study were $I$. nil cv. Scarlet O'Hara and N. benthamiana. SPFMV (27) was propagated in I. nil. SPFMV does not infect $N$. benthamiana (27). The seeds of $I$. nil and SPFMV were provided by T. Usugi, (Japan International Research Center for Agricultural Sciences, Okinawa Branch, Japan). The PVX vector (pP2C2S), a derivative of pGC3 (7), was provided by D. C. Baulcombe (The Sainsbury Laboratory, Norwich, United Kingdom). The PVX vector, hereafter referred to as PVX, was propagated in $N$. benthamiana.

Virus inoculation. Virus-infected leaf homogenates were used as an inoculum. In mixed inoculation, leaves systemically infected with each virus were ground in $0.1 \mathrm{M}$ phosphate buffer $(\mathrm{pH} \mathrm{8.0)}$ at a ratio of 1:10 (wt/vol) and equal volumes of the extracts were mixed for a final 1:20 dilution of each virus. For single inoculations, leaves were ground at a 1:20 (wt/vol) ratio. Mechanical inoc- 
ulations were made on the cotyledonary leaves of $I$. nil, and the plants were incubated at 22 to $25^{\circ} \mathrm{C}$.

Analyses of viral RNAs. The levels of viral RNAs were examined by RNA gel blot analysis. Total RNAs were isolated from the inoculated cotyledonary and the first upper true leaves at 14 days postinoculation (dpi) as described by Sonoda et al. (24). Routine RNA manipulation was performed according to Sambrook et al. (20). Five to ten micrograms of total RNAs was size-fractionated on $1.2 \%$ agarose gel containing $0.66 \mathrm{M}$ formaldehyde and transferred to Hybond $\mathrm{N}+$ (Amersham Life Science, Buckinghamshire, United Kingdom).

Radioactive cDNA probes complementary to the PVX (+) and (-) strand RNAs were generated as follows. The ApaI-SacI fragment of PVX (nucleotides 4945 to 6553) (D. C. Baulcombe, personal communication) was cloned into similarly digested pCRScript SK (+) (Stratagene, La Jolla, CA). The recombinant plasmid linearized with ApaI and the recombinant linearized with $\mathrm{SacI}$ were used for transcription reactions with T3 (Stratagene) and T7 (Gibco BRL, Rockville, MD) RNA polymerases, respectively. In vitro transcription reactions were described previously (24). The resulting transcripts were labeled with hexanucleotide random primers and Moloney murine leukemia virus (MMLV) reverse transcriptase (Toyobo, Osaka, Japan). For SPFMV, a random-primed radioactive probe containing the coat protein coding sequence was generated. The levels of viral RNAs on RNA blots were analyzed by autoradiography using X-ray film (Fuji, RX-U, Tokyo, Japan) and quantitated using the BAS 2000 system (Fuji).

PVX constructs and inoculation. We constructed PVX derivative PVX.HC by cloning the HC-Pro gene of SPFMV into the PVX vector in a sense-orientation. The gene encoding the HC-Pro of SPFMV genome (nucleotides 2110 to $3483 ; 19$ ) was amplified by polymerase chain reaction (PCR). PCR conditions were as follows: 30 cycles of $1 \mathrm{~min}$ at $94^{\circ} \mathrm{C}, 2 \mathrm{~min}$ at $45^{\circ} \mathrm{C}, 2 \mathrm{~min}$ at $72^{\circ} \mathrm{C}$, and 1 cycle of $7 \mathrm{~min}$ at $72^{\circ} \mathrm{C}$. The $5^{\prime}$ end PCR primer $5^{\prime}-$ GGGTCGACACAATGAGCTCTACTATGGAAAGATTTC-3' encoded a SalI restriction site (underlined) and sequences complimentary to SPFMV (bold), including a translational start codon. The $3^{\prime}$ end PCR primer 5'-CCGTCGACCTAGCCTACTATGTAGTGTTTCATC-3' encoded a SalI restriction site (underlined) and sequences complimentary to SPFMV (bold), including a translational stop codon. The resulting PCR-amplified fragment of the HC-Pro gene was digested with SalI and cloned into the SalI cloning site of the PVX vector. The expression of the HC-Pro insert is under the control of the duplicated PVX coat protein subgenomic promoter. The orientation and nucleotide sequences of the HC-Pro coding sequence in the construct were confirmed by nucleotide sequencing. The modified and unmodified PVX constructs were transcribed in vitro (24) and inoculated on $N$. benthamiana. The leaf homogenates diluted (1:10) in $10 \mathrm{mM}$ phosphate buffer ( $\mathrm{pH}$ 7.0) were used for virus inoculation.

Preparation of polyclonal antibody against SPFMV HCPro. The gene encoding the HC-Pro of SPFMV genome was amplified by PCR. PCR conditions were 30 cycles of $1 \mathrm{~min}$ at $94^{\circ} \mathrm{C}$, $2 \mathrm{~min}$ at $52^{\circ} \mathrm{C}$, and $3 \mathrm{~min}$ at $72^{\circ} \mathrm{C}$. The $5^{\prime}$ end PCR primer $5^{\prime}-$ GGTCTAGAACAATGAGCTCTCTACTATGGAAAGATTTC-3' encoded a $X b a \mathrm{I}$ restriction site (underlined) and sequences complimentary to SPFMV (bold), including a translational start codon. The $3^{\prime}$ end PCR primer 5'-CCAAGCTTCTAGCCTACTATGTAGTGTTTCATC-3' consisted of sequences complimentary to SPFMV (bold), including a translational stop codon and a HindIII restriction site (underlined). After digestion of the PCR product with $X b a I$ and HindIII, the DNA was inserted into the similarly digested plasmid, pRSET-B (Invitrogen, NV Leek, the Netherlands). The fusion protein of $\approx 54 \mathrm{kDa}$ was overexpressed in Escherichia coli XL1-blue in the presence of isopropyl- $\beta$-D-thiogalactopyranoside (IPTG) and was isolated by sodium dodecyl sulfatepolyacrylamide gel electrophoresis and electroelution. The isolated fusion protein was used to raise polyclonal antibodies in rabbits.

Immunofluorescence microscopy. Leaves of $I$. nil systemically infected with SPFMV were harvested at 14 dpi and fixed in a washing buffer $(50 \mathrm{mM}$ sodium cacodylate buffer at $\mathrm{pH} 7.4$ ) supplemented with paraformaldehyde at a final concentration of $4 \%(\mathrm{wt} / \mathrm{vol})$ for $2 \mathrm{~h}$ at $4{ }^{\circ} \mathrm{C}$. After fixation, the tissue samples were embedded in 5\% (wt/vol) Type II agarose (Sigma Chemical Co., St. Louis) blocks. Sections (50 to $80 \mu \mathrm{m}$ ) were prepared with a microslicer (DTK-1000, Dohsaka, Kyoto, Japan), dried on aminopropyltriethoxysilane-coated slide glasses (Matsunami Glass, Osaka, Japan), and encircled with peroxidase-antiperoxidase pen (Daido Sangyo, Takaoka, Japan) for immunological reaction. The sections were treated with $40 \mu \mathrm{l}$ of enzyme solution, $(0.1 \%$, wt/vol) Pectolyase Y-23 (Kikkoman, Tokyo, Japan) in phosphate-buffered saline (PBS) buffer for $2 \mathrm{~h}$ at $30^{\circ} \mathrm{C}, 40 \mu \mathrm{l}$ of detergent solution, and $0.3 \%$ (vol/vol) Triton X-100 in PBS buffer for $2 \mathrm{~h}$ at $30^{\circ} \mathrm{C}$. Cell wall and membrane permeabilized-samples were incubated in $40 \mu \mathrm{l}$ of blocking solution, 5\% (wt/vol) bovine serum albumin, $0.02 \%$ (wt/vol) sodium azide in PBS buffer for $10 \mathrm{~min}$, and exposed at $37^{\circ} \mathrm{C}$ for $12 \mathrm{~h}$ to a $1: 1,000$ dilution of rabbit polyclonal antibody raised against SPFMV HC-Pro. After incubation in $40 \mu \mathrm{l}$ of blocking solution for $10 \mathrm{~min}$, the sections were exposed to a 1:250 dilution of flourescein isothiocyanate-labeled goat anti-rabbit immunoglobulin (Ig)G for $1 \mathrm{~h}$ at room temperature and immersed in antifade reagent (SlowFade, Molecular Probes, Eugene,

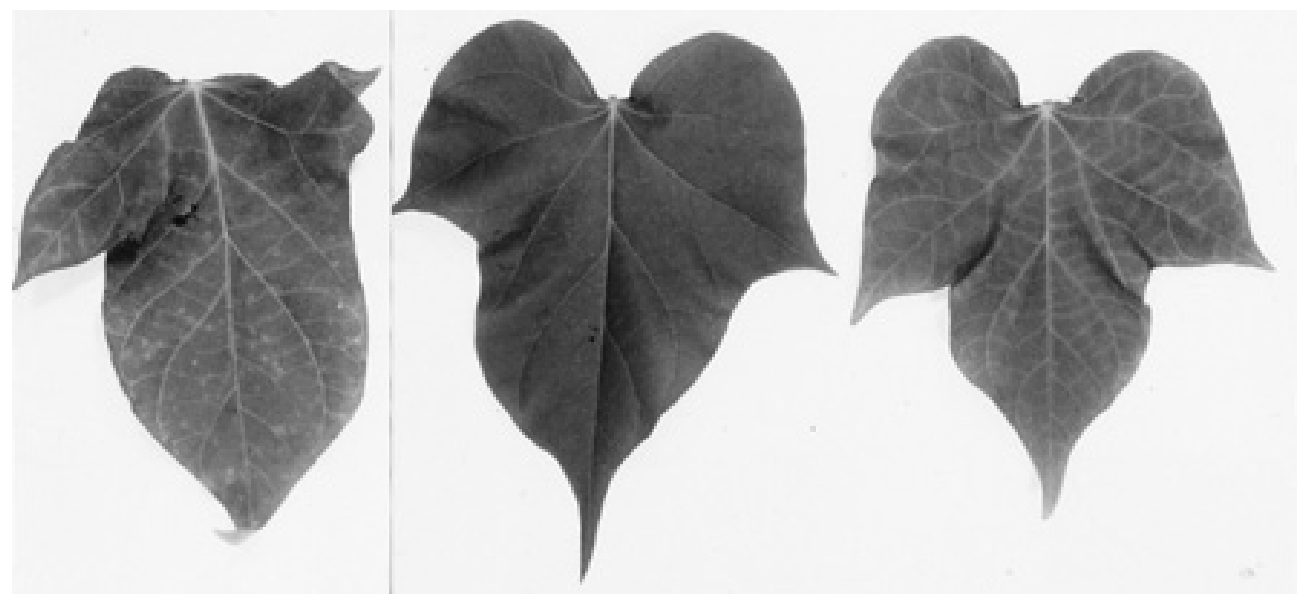

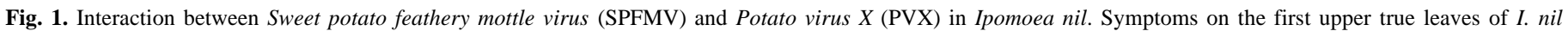
infected with SPFMV (right), PVX (middle), and both SPFMV and PVX (left). 


\section{A PVX (+) strand RNA}

Inoculated cotyledonary leaves

\section{$\begin{array}{llllllllllllllllll}1 & 2 & 3 & 4 & 5 & 6 & 7 & 8 & 9 & 10 & 11 & 12 & 13 & 14 & 15 & 16 & 17 & 18\end{array}$}

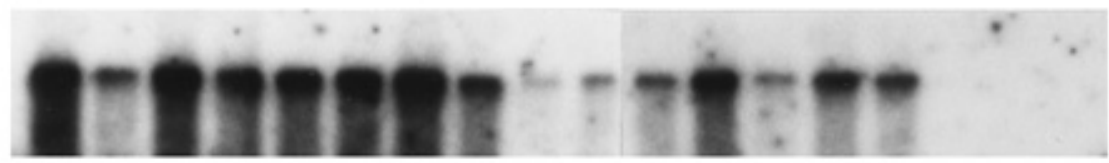

First upper true leaves

\section{$\begin{array}{llllllllllllllllll}1 & 2 & 3 & 4 & 5 & 6 & 7 & 8 & 9 & 10 & 11 & 12 & 13 & 14 & 15 & 16 & 17 & 18\end{array}$}

\section{B PVX (-) strand RNA}

\section{Inoculated cotyledonary leaves}

\section{$\begin{array}{llllllllllllllllll}1 & 2 & 3 & 4 & 5 & 6 & 7 & 8 & 9 & 10 & 11 & 12 & 13 & 14 & 15 & 16 & 17 & 18\end{array}$}

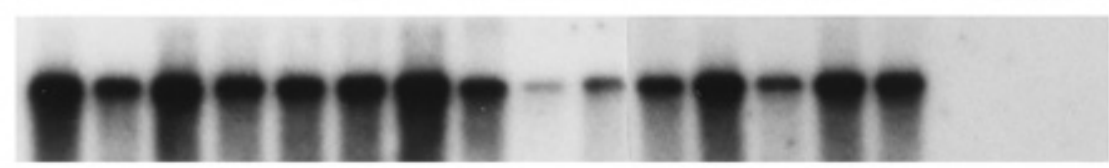

First upper true leaves

\section{$\begin{array}{llllllllllllllllll}1 & 2 & 3 & 4 & 5 & 6 & 7 & 8 & 9 & 10 & 11 & 12 & 13 & 14 & 15 & 16 & 17 & 18\end{array}$}

\section{SPFIV-S RNA}

Inoculated cotyledonary leaves

\section{$\begin{array}{llllllllll}1 & 2 & 3 & 4 & 5 & 6 & 7 & 8 & 9 & 10\end{array}$}

Fig. 2. A, RNA gel blot analysis for the detection of Potato virus $X$ (PVX (+)) strand RNA. B, RNA gel blot analysis for the detection of PVX (-) strand RNA. C, RNA gel blot analysis for the detection of Sweet potato feathery mottle virus (SPFMV) RNA. Total RNA (5 to $10 \mu \mathrm{g} / \mathrm{lane}$ ) isolated from plants infected with PVX (Lanes 1 to 8), both SPFMV and PVX (A and B, Lanes 9 to 15; and C, Lanes 1 to 7), SPFMV (A and B, Lanes 16 and 17; and $\mathbf{C}$, Lanes 8 and 9), or from healthy Ipomoea nil (A and B, Lane 18; and C, Lane 10) were subjected to denaturing gel electrophoresis, transferred to nylon membrane, and hybridized with radioactive PVX (+), (-) strand RNA, or SPFMV-CP specific probe. 
OR) for observation. The fluorescence was visualized on a confocal laser scanning microscope (Model CLSM310, Carl Zeiss Inc., Oberkochen, Germany) with argon laser (488 $\mathrm{nm}$ ) and BP515-565 filter. Images were directly recorded in .TIFF format and processed with Adobe Photoshop version 3.03J to generate pseudocolors with a Power Macintosh (Apple Computer Inc., Cupertino, CA).

\section{RESULTS}

Interaction between SPFMV and PVX in I. nil. To examine the symptom appearance of SPFMV and PVX in I. nil, the cotyledonary leaves were mechanically inoculated with SPFMV, PVX, or both viruses. After $14 \mathrm{dpi}$, the first upper true leaves of plants

A PVX

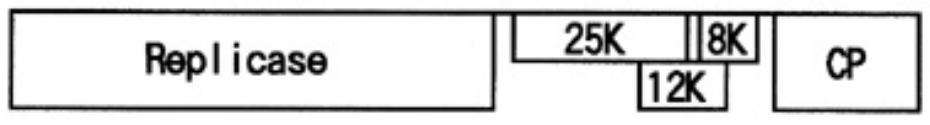

PVX. HC

\begin{tabular}{|l|l|l|l|l|}
\hline Repl icase & 25K & LEK & HC-Pro & CP \\
\hline
\end{tabular}

B

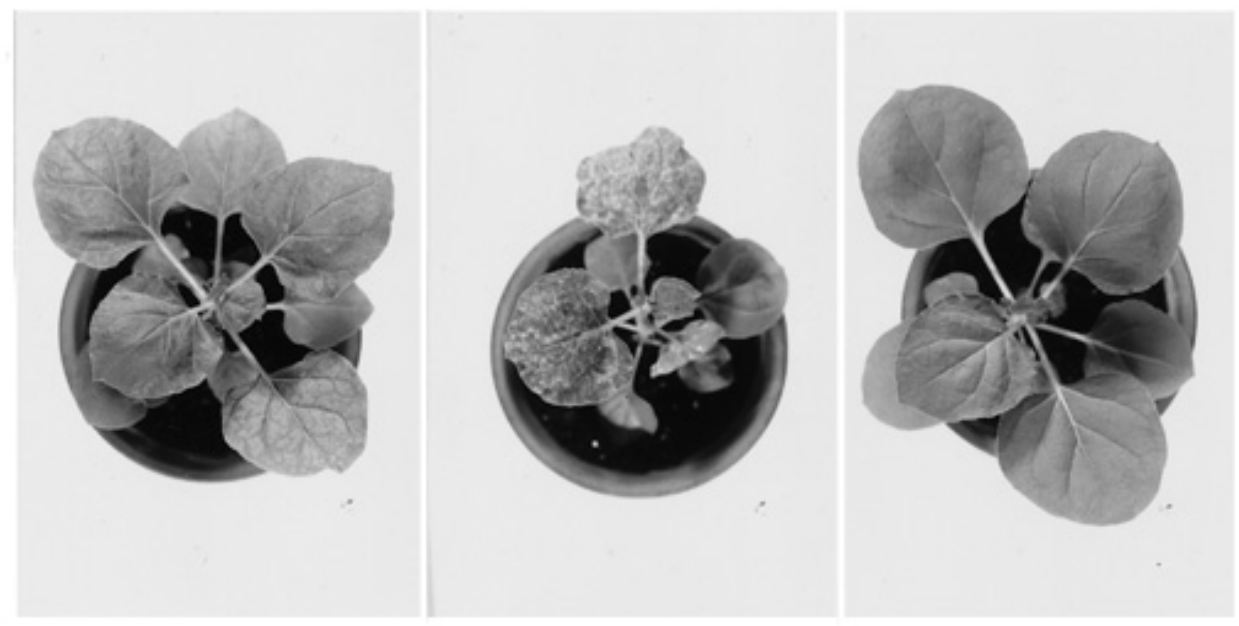

C PVX (+) strand RNA

Inoculated cotyledonous leaves

$\begin{array}{lllllllllllllllll}1 & 2 & 3 & 4 & 5 & 6 & 7 & 8 & 9 & 10 & 11 & 12 & 13 & 14 & 15 & 16 & 17\end{array}$

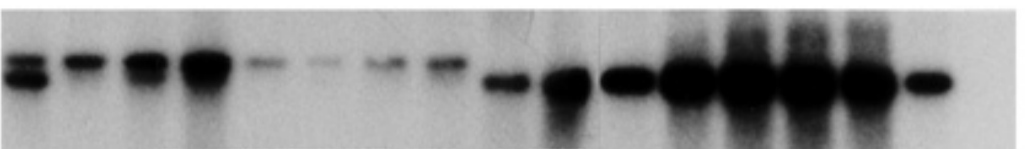

First upper true leaves

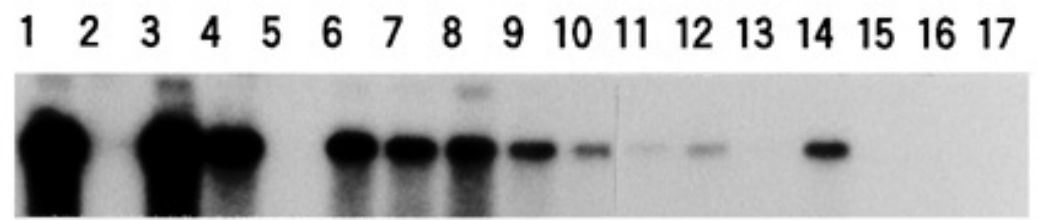

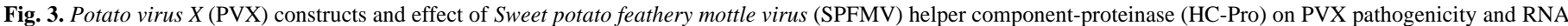

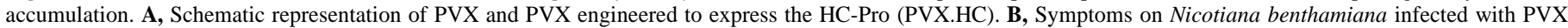

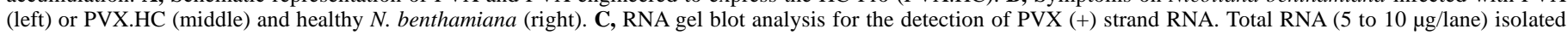

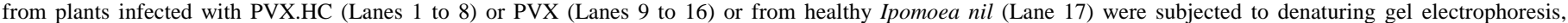
transferred to a nylon membrane, and hybridized with a radioactive PVX (+) strand RNA specific probe. 
infected with SPFMV alone or coinfected with PVX and SPFMV developed typical symptoms (veinclearing) by SPFMV (Fig. 1, left and right). On the first upper true leaves of the coinfected plants, chlorotic spots caused by PVX that coalesced along the vein were superimposed on the veinclearing (Fig. 1, left). In contrast, no such symptom was observed on the first upper true leaves of plants infected with PVX alone by 14 dpi (Fig. 1, middle). Thus, symptom severity was enhanced by the coinfection. However, diffused chlorotic spots appeared on some of the first upper true leaves of plants infected with PVX alone at 28 dpi (data not shown).

The accumulation and movement of SPFMV and PVX were examined in I. nil infected with SPFMV, PVX, or both viruses with RNA gel blot analysis. At 14 dpi, the inoculated cotyledonary and the first upper true leaves were harvested and used for the analysis. In plants coinfected with SPFMV and PVX, PVX (+) strand genomic RNA was detected in the inoculated cotyledonary leaves and in the first upper true leaves (Fig. 2A, Lanes 9 to 15). When plants were infected with PVX alone, PVX (+) strand RNA was detected in the inoculated cotyledonary leaves but not in the first upper true leaves (Fig. 2A, Lanes 1 to 8). However, PVX (+) strand RNA was detected in some of the first upper true leaves of plants infected with PVX alone at 28 dpi (data not shown). The levels of PVX (+) strand RNA in the inoculated cotyledonary leaves were higher in plants infected with PVX alone (Fig. 2A). Because potyviruses induce a disproportionate increase in PVX (-) strand RNA accumulation in the first upper true leaves of Nicotiana plants (28), we examined the levels of PVX (-) strand RNA in $I$. nil at 14 dpi by RNA gel blot analysis. No apparent increase in PVX (-) strand RNA accumulation was observed in inoculated cotyledonary and first upper true leaves of the coinfected plants (Fig. 2B). SPFMV RNA accumulation remained unchanged, regardless of whether the inoculum consisted of SPFMV alone or a mixture of SPFMV and PVX (data for the inoculated cotyledonary shown in Fig. 2C). These results suggest
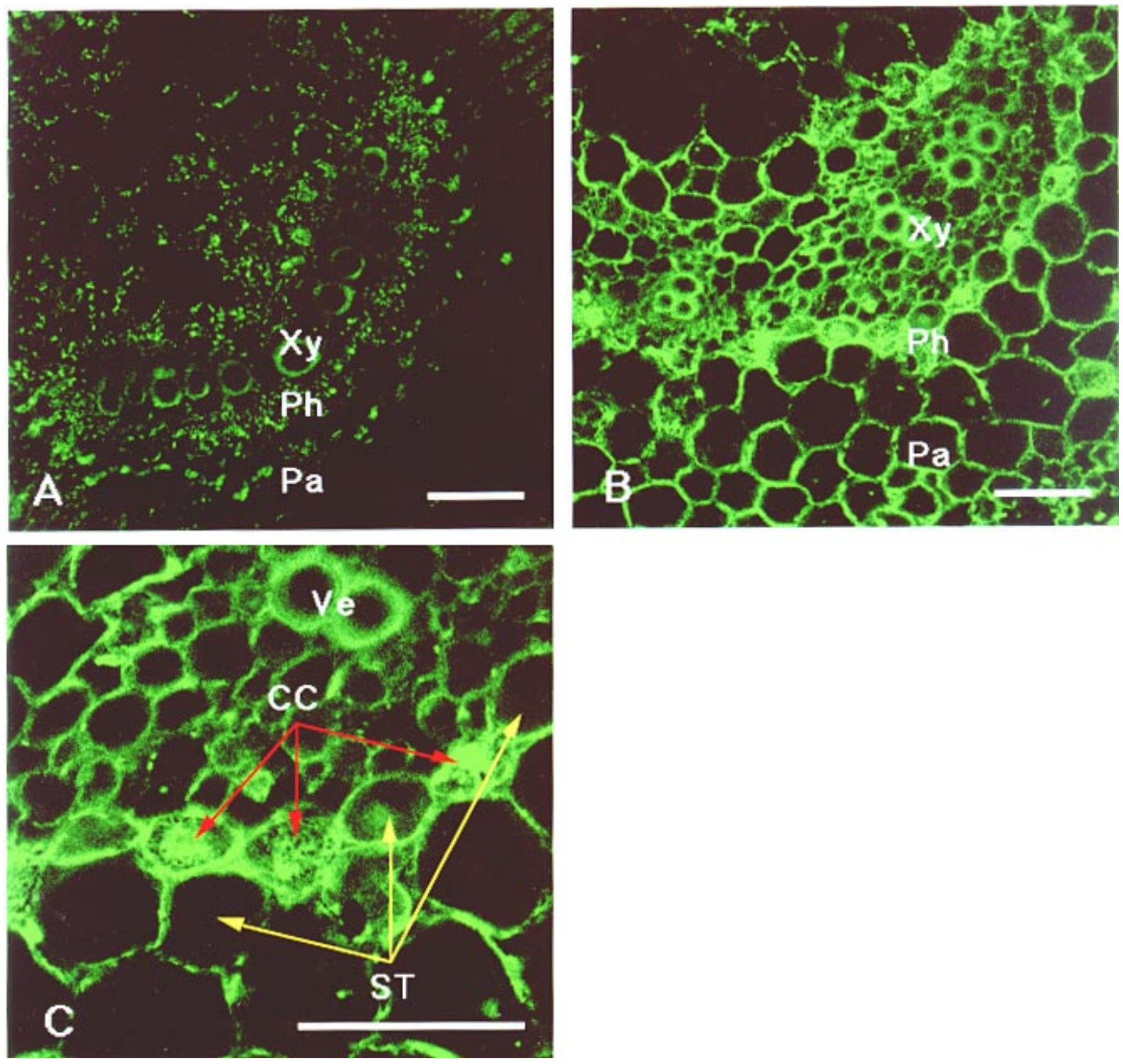

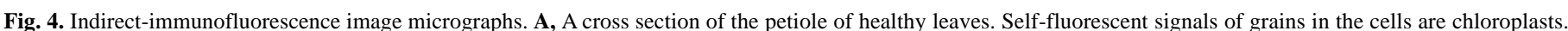

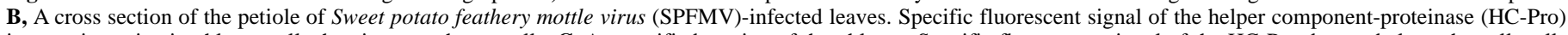

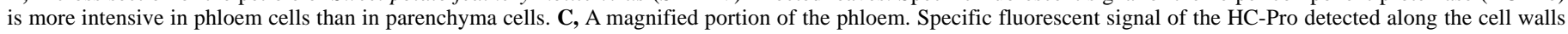

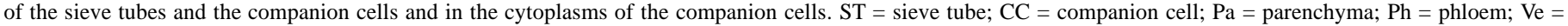
vessel; Xy = Xylem; and bar $=100 \mu \mathrm{m}$. 
that the long distance movement of PVX was enhanced by SPFMV in I. nil.

Effect of SPFMV HC-Pro expression on PVX. Pruss et al. (17) showed that the recombinant PVX engineered to express TEV-encoded HC-Pro produced symptoms much more severe than those of the recombinant PVX engineered to express the nontranslatable version of the gene in $N$. benthamiana. We introduced the HC-Pro gene of SPFMV into the PVX vector and analyzed the effects of the HC-Pro gene expression on PVX pathogenicity, replication, and movement in $I$. nil. The PVX constructs used in this study are illustrated in Figure 3A.

To examine whether the recombinant PVX expressing the HCPro of SPFMV produces severe symptoms in Nicotiana plants as reported by Pruss et al. (17) using HC-Pro from TEV, N. benthamiana was mechanically inoculated with PVX or PVX.HC. $N$. benthamiana infected with PVX showed symptoms at 5 dpi. At $14 \mathrm{dpi}$, the infected plants exhibited veinclearing and chlorotic mosaic (Fig. 3B, left). N. benthamiana infected with PVX.HC showed a 2- to 5-day delay in symptom appearance compared with PVX. PVX.HC-infected plants initially exhibited veinclearing and severe mottling and sometimes necrosis of the systemic leaves by 14 dpi (Fig. 3B, middle). These results suggest that the HC-Pro of SPFMV has an ability to increase PVX pathogenicity in $N$. benthamiana. However, the accumulation of PVX $(+)$ strand RNA in the systemic leaves of PVX.HC-infected plants was not higher than that of PVX-infected plants (data not shown). The insertion of a foreign gene in the PVX vector debilitates the infectivity (7). In this regard, the presence of the HC-Pro gene of SPFMV in PVX might mask the effect of the protein product as a replication enhancer for unrelated viruses. Alternatively, SPFMV HC-Pro might not act as the replication enhancer in the nonhost, N. benthamiana.

When $I$. nil was infected with a 1:10 dilution of PVX or PVX.HC, some plants showed symptoms characterized by chlorotic spots that often coalesced along the vein on the first systemic leaves by 14 dpi. However, PVX-infected plants developed symptoms more slowly compared with PVX.HC-infected plants (data not shown). The levels of PVX (+) strand RNA in the inoculated cotyledonary and the first upper true leaves were examined by RNA gel blot analysis. In the inoculated cotyledonary leaves, PVX (+) strand RNA accumulation in PVX-infected plants was $\approx 3.5$-fold higher than that in PVX.HC-infected plants (Fig. 3C). The presence of the HC-Pro in the inoculated cotyledonary leaves infected with PVX.HC was confirmed by western blotting (data not shown). In the first upper true leaves, PVX (+) strand RNA was detected in six of eight PVX.HC-infected plants. Similar frequency of virus detection in the first upper true leaves was observed in PVX-infected plants (five of eight plants tested). However, in the first upper true leaves, PVX (+) strand RNA accumulation in PVX.HC-infected plants was $\approx 10.6$-fold higher than that in PVX-infected plants (Fig. 3C). The PVX molecules observed in the first upper true leaves of PVX.HC-infected plants were mostly the wildtype PVX (Fig. 3C). These results suggest that the HC-Pro acts as a trans acting enhancer for the movement of PVX in I. nil.

Immunolocalization of SPFMV HC-Pro in infected leaves. The localization of SPFMV HC-Pro in the infected first upper true leaves of $I$. nil was examined by indirect-immunofluorescence microscopy (Fig. 4). Specific fluorescent signal of the HC-Pro was localized along the cell walls of phloem and parenchyma cells (Fig. 4B and C). However, the level of fluorescent signal in phloem was much higher than that in parenchyma cells (Fig. 4B and $\mathrm{C}$ ). The signal was also detected in the central part of phloem, possibly companion cells (Fig. 4B and C).

\section{DISCUSSION}

In the present study, we have shown that the interaction between SPFMV and PVX in I. nil was characterized by more efficient long distance movement of PVX as well as an increase in symptom severity. A similar interaction was observed between SPFMV and a wasabi strain of Crucifer tobamovirus (CTMV; 23), a member of the genus Tobamovirus, in I. nil. When plants were coinfected with SPFMV and CTMV, CTMV RNA was detected in the first upper true leaves of most plants (89\%) at 14 dpi (17 of 19 plants tested). On the other hand, CTMV RNA was detected in the first upper true leaves in 9 of 16 plants inoculated with CTMV alone (56\%) at $14 \mathrm{dpi}$ (S. Sonoda and M. Nishiguchi, unpublished data). SPFMV RNA accumulation remained unchanged, regardless of whether the inoculum consisted of SPFMV alone or a mixture of SPFMV and CTMV (S. Sonoda and M. Nishiguchi, unpublished data). These results suggest that SPFMV has a potential to enhance long distance movement for unrelated viruses in I. nil. These effects of SPFMV on the unrelated viruses in I. nil shared classic features of a synergism caused by plant viruses, including increased virus accumulation and symptoms and more rapid systemic spread of the virus $(11,25,28)$. However, the synergistic features observed in this study were not consistent with the description of the potyvirus-induced synergism in Nicotiana plants $(17,28,29)$. In these cases, the potyvirus-induced synergisms have been mainly involved in the transactivation of viral replication associated with P1/HC-Pro (17), although a role in movement was not ruled out. Furthermore, recently the transactivation of viral replication was postulated to be due to suppression of the host defense mechanism by HC-Pro $(1,5,12)$. In the present study, we showed that the expression of SPFMV HC-Pro in the PVX vector enhanced PVX pathogenicity in $I$. nil, although to a lesser degree (data not shown) than in N. benthamiana (Fig. 3B). The long distance movement of PVX was enhanced by the HCPro in I. nil. It was not apparent and might be masked in $N$. benthamiana because of the use of inappropriate control for this plant species. This indicates that potyviral HC-Pro interacts synergistically through several functions.

Potyviral HC-Pro is a multifunctional protein (14). In addition to its role as a helper component for aphid transmission (26), HCPro functions as a proteolytic enzyme and is responsible for the release of its own $\mathrm{C}$ terminus from the polyprotein (6). The involvement of the HC-Pro gene in virus replication and symptom expression has been shown in TVMV $(3,4)$. Furthermore, the central region of HC-Pro provides a function essential for long distance movement of TEV in plants (8). Therefore, a role in long distance movement for an unrelated virus is quite possible for the HC-Pro. The observation that SPFMV HC-Pro localized in the phloem of $I$. nil also support this idea (Fig. 4). Since HC-Pro acts as a sequence nonspecific RNA-binding protein which preferentially binds single-stranded RNA over DNA or double-stranded RNA (13), SPFMV HC-Pro may enter the phloem along with unrelated viral RNAs and facilitate their movement in I. nil. Furthermore, localization of the HC-Pro in parenchyma cells surrounding the vascular bundles implies the involvement of the $\mathrm{HC}$ Pro in cell-to-cell movement for unrelated viruses. Kasschau and Carrington (12) mentioned that the effective long distance movement of TEV requires a silencing-suppression function. The CMV 2b (9) and Tomato bushy stunt virus p19 (22) proteins have been known as long distance movement factors. The in planta localization of these proteins has never been reported yet. It may be interesting to know the localization of a long distance movement factor in planta and the relationship between the factor and the function of gene silencing suppression.

It has been proposed that systemic spread of TEV involves an interaction between HC-Pro and coat protein (or virion; 8). The involvement of the VPg in systemic spread was also proposed from the analysis of TEV recombinants made between strains showing different capacities for systemic spread in tobacco plants (21). Therefore, we do not rule out the possibility that SPFMV coat protein and VPg also contribute to the facilitation of the movement of unrelated viruses in conjunction with the HC-Pro. 
Potyvirus-mediated interactions with unrelated viruses have been reported so far. When resistant Capsicum annuum cv. Avelar plants that suppress the systemic spread of Pepper mottle virus (PepMoV), a member of the genus Potyvirus, were coinfected with PepMoV and CMV, PepMoV accumulation was no longer restricted within the inoculated leaves (16). In this case, the systemic spread of PepMoV was enhanced by CMV. Bean yellow mosaic virus and Peanut mottle virus, members of the genus Potyvirus, did not interact synergistically with Bean pod mottle virus (BPMV) of the genus Comovirus in coinfected soybean plants, although soybean plants coinfected with Soybean mosaic virus, a member of the genus Potyvirus and one of two comoviruses, Cowpea mosaic virus or BPMV, showed greatly increased symptom severity over that induced by the individual viruses (2). These results suggest that potyviruses do not always interact synergistically with unrelated viruses. In plant-virus interactions, plants may have evolved defense mechanisms against viral invasion, whereas viruses would evolve strategies to avoid or suppress the mechanism. A further study on the effects of potyvirus on both unrelated viruses and on the host plants might provide a better understanding of plant defense mechanisms.

\section{ACKNOWLEDGMENTS}

This research was supported, in part, by the Grant-in-Aid "Integrated Research Program for the Use of Biotechnological Procedures for Plant Breeding" from the Ministry of Agriculture, Forestry and Fisheries of Japan. We thank D. C. Baulcombe (The Sainsbury Laboratory, Norwich, United Kingdom) for providing the Potato virus $X$ vector, T. Usugi (Japan International Research Center for Agricultural Sciences, Okinawa Branch, Japan) for providing Sweet potato feathery mottle virus and the seeds of Ipomoea nil, and the Japan Science and Technology Corporation for the award of a Domestic Research Fellowship to S. Sonoda.

\section{LITERATURE CITED}

1. Anandalakshmi, R., Pruss, G. J., Ge, X., Marathe, R., Mallory, A. C., Smith, T. H., and Vance, V. B. 1998. A viral suppresser of gene silencing in plants. Proc. Natl. Acad. Sci. USA 95:13079-13084.

2. Anjos, J. R., Jarlfors, U., and Ghabrial, S. A. 1992. Soybean mosaic potyvirus enhances the titer of two comoviruses in dually infected soybean plants. Phytopathology 82:1022-1027.

3. Atreya, C. D., Atreya, P. L., Thornbury, D. W., and Pirone, T. P. 1992. Site-directed mutations in the potyvirus HC-Pro gene affect helper component activity, virus accumulation, and symptom expression in infected tobacco plants. Virology 191:106-111.

4. Atreya, C. D., and Pirone, T. P. 1993. Mutational analysis of the helper component-proteinase gene of a potyvirus: Effects of amino acid substitutions, deletions, and gene replacement on virulence and aphid transmissibility. Proc. Natl. Acad. Sci. USA 90:11919-11923.

5. Brigneti, G., Voinnet, O., Li, W.-X., Ji, L.-H., Ding, S.-W., and Baulcombe, D. C. 1998. Viral pathogenicity determinants are suppressers of transgene silencing in Nicotiana benthamiana. Eur. Mol. Biol. Organ. J. 17:6739-6746.

6. Carrington, J. C., Cary, S. M., Parks, T. D., and Dougherty, W. G. 1989. A second proteinase encoded by a plant potyvirus genome. Eur. Mol. Biol. Organ. J. 8:365-370.

7. Chapman, S., Kavanagh, T., and Baulcombe, D. 1992. Potato virus X as a vector for gene expression in plants. Plant J. 2:549-557.

8. Cronin, S., Verchot, J., Haldeman-Cahill, M. C., Schaad, M. C., and Carrington, J. C. 1995. Long-distance movement factor: A transport function of the potyvirus helper component proteinase. Plant Cell 7:549-559.

9. Ding, S.-W., Li, W.-X., and Symons, R. H. 1995. A novel naturally occurring hybrid gene encoded by a plant RNA virus facilitates long distance virus movement. Eur. Mol. Biol. Organ. J. 14:5762-5772.

10. Dougherty, W. G., and Carrington, J. C. 1988. Expression and function of potyviral gene products. Annu. Rev. Phytopathol. 26:123-143.

11. Fuentes, A. L., and Hamilton, R. I. 1991. Sunn-hemp mosaic virus facilitates cell-to-cell spread of southern bean mosaic virus in a nonpermissive host. Phytopathology 81:1302-1305.

12. Kasschau, K. D., and Carrington, J. C. 1998. A counterdefensive strategy of plant viruses: Suppression of posttranscriptional gene silencing. Cell 95:461-470.

13. Maia, I. G., and Bernardi, F. 1996. Nucleic acid-binding properties of a bacterially expressed potato virus $\mathrm{Y}$ helper component-proteinase. J. Gen. Virol. 77:869-877.

14. Maia, I. G., Haenni, A. L., and Bernardi, F. 1996. Potyviral HC-Pro: A multifunctional protein. J. Gen. Virol. 77:1335-1341.

15. Matthews, R. E. F. 1991. Plant Virology, 3rd ed. Academic Press, San Diego, CA.

16. Murphy, J. F., and Kyle, M. M. 1995. Alleviation of restricted systemic spread of pepper mottle potyvirus in Capsicum annuum cv. Avelar by coinfection with a cucumovirus. Phytopathology 85:561-566.

17. Pruss, G., Ge, X., Shi, X. M., Carrington, J. C., and Vance, V. B. 1997. Plant viral synergism: The potyviral genome encodes a broad-range pathogenicity enhancer that transactivates replication of heterologous viruses. Plant Cell 9:859-868.

18. Riechmann, J. L., Lain, S., and Garcia, J. A. 1992. Highlights and prospects of potyvirus molecular biology. J. Gen. Virol. 73:1-16.

19. Sakai, J., Mori, M., Morishita, T., Tanaka, M., Hanada, K., Usugi, T., and Nishiguchi, M. 1997. Complete nucleotide sequence and genome organization of sweet potato feathery mottle virus ( $S$ strain) genomic RNA: The large coding region of the P1 gene. Arch. Virol. 142:15531562.

20. Sambrook, J., Fritsch, E. F., and Maniatis, T. 1989. Molecular Cloning. 2nd ed. Cold Spring Harbor Laboratory, Cold Spring Harbor, New York.

21. Schaad, M. C., Lellis, A. D., and Carrington, J. C. 1997. VPg of tobacco etch potyvirus is a host genotype-specific determinant for long distance movement. J. Virol. 71:8624-8631.

22. Scholthof, H. B., Scholthof, K.-B. G., Kikkert, M., and Jackson, A. O. 1995. Tomato bushy stunt virus spread is regulated by two nested genes that function in cell-to-cell movement and host-dependent systemic invasion. Virology 213:425-438.

23. Shimamoto, I., Sonoda, S., Vazquez, P., Minaka, N., and Nishiguchi, M. 1998. Nucleotide sequence analysis of the $3^{\prime}$ terminal region of a wasabi strain of crucifer tobamovirus genomic RNA: Subgrouping of crucifer tobamoviruses. Arch. Virol. 143:1801-1813.

24. Sonoda, S., Mori, M., and Nishiguchi, M. 1999. Homology-dependent virus resistance in transgenic plants with the coat protein gene of sweet potato feathery mottle potyvirus: Target specificity and transgene methylation. Phytopathology 89:385-391.

25. Taliansky, M. E., Malyshenko, S. I., Pshennikova, E. S., Kaplan, J. B., Ulanova, E. F., and Atabekov, J. G. 1982. Plant virus specific transport function. I. Virus genetic control required for systemic spread. Virology 122:318-326.

26. Thornbury, D. W., Hellmann, G. M., Rhoads, R. E., and Pirone, T. P. 1985. Purification and characterization of potyvirus helper component. Virology 144:260-267.

27. Usugi, T., Nakano, M., Onuki, M., Maoka, T., and Hayashi, T. 1994. A new strain of sweet potato feathery mottle virus that causes russet crack on fleshy roots of some Japanese cultivars of sweet potato. Ann. Phytopathol. Soc. Jpn. 60:545-554.

28. Vance, V. B. 1991. Replication of potato virus X RNA is altered in coinfections with potato virus Y. Virology 182:486-494.

29. Vance, V. B., Berger, P. H., Carrington, J. C., Hunt, A. G., and Shi, X. M. 1995. 5' Proximal potyviral sequences mediate potato virus $\mathrm{X} /$ potyviral synergistic disease in transgenic tobacco. Virology 206:583-590. 